The preparations of the dermo-muscular tissue of human embryos were treated with the virus within $20 \mathrm{~min}$ at $4^{\circ} \mathrm{C}$; residual virus was removed by triple washing in the cold Hanks's solution; then Medium 199 with 10 per cent serum and ${ }^{14} \mathrm{C}$-adenine, $0.01 \mu \mathrm{c} . / \mathrm{ml}$., were added and preparations were incubated at $37^{\circ} \mathrm{C}$. After exposure for $3 \mathrm{~h}$, cells were washed with Hanks's solution, fixed in Carnoy's solution, covered with $\gamma$-globulin labelled with iodine-131, exposed for $20 \mathrm{~min}$ and then washed again. Then they were covered with film, type $M R$, and exposed with silica gel in the dark at $4^{\circ} \mathrm{C}$ for 7 days. Developed preparations were stained with mothylene bluo.

Fig. 1 domonstrates some results of the method. of the double radioactive labelling. ${ }^{14} \mathrm{C}$-adenine as nucleic acid precursor is presented as small points randomly scattered while $\gamma$-globulin labelled with iodine-131, blocking viral antigen, forms large autographs and conglomerates. So far as carbon-14 and iodine-131 have different energies of decay, it is possible to observe simultaneously the reproduction of viral nucleic acid and protoin as autographs of different size in the same cell.

V. M. ZHDANOV

Y. M. Zhantieva

V. M. StakhaNova

D.I. Ivanovski Institute of Virology, Moscow.

1 Zhdanov, V. M., in Physiology and Genetics of Viruses, 7 (Moscow, 1961) (in Russian).

2 Hoyle, 'T. L., and Finter, N., J. Hyg., 55, 290 (1957).

${ }^{3}$ Francis, G. E., Mulligan, W., and Wormall, A., Nature, 167, 748 (1951).

' Liebster, J., Babicky, A., and Kosel, J., Folia Biol. (Prague), 3, 183 (1957).

\section{Effect of Actinomycin D on Measles Virus Growth and Interferon Production}

Acrinomycin $D$ combines in vitro with DNA in mammalian colls and results in impairment of DNA synthesis and of DNA-depondent RNA synthesisis, This results in uncoupling DNA from cellular protoin synthesis.

Certain animal riboviruses (polio, mengo and Newcastle disease viruses (NDV)) have been shown to replicate in actinomycin $D$ treated cultures, indicating their independence of collular nucleic acid function ${ }^{2,5}$.

Interferon production in cell cultures occurs in response to treatment of cells with foreign nucleic acids ${ }^{6}$. Becauso actinomycin $D$ inhibits cellular RNA synthesis and hence protein synthesis, it would be expected to inhibit production of interferon.

Bukrinskaya and Zhdanov ${ }^{7}$ demonstrated a docroase in the latent period of Sendai virus production in actinomycin $D$ treated chick fibroblasts. They attempted to explain their results by suggesting that actinomycin $D$ may have inhibited messenger-RNA of the cell, resulting in early direction of cellular enzymatic systems to virus production.

Treatment of chick fibroblasts with actinomycin $D$ prior to inoculation with Chikungunya virus resulted in inhibition of interferon production accompanied by enhancement of viral growth ${ }^{8,8}$. Actinomycin $D$ has also boon shown to cause enhancement of growth of Semliki forest virus (SFV) and NDV (ref. 10).

This communication reports preliminary investigation of the offects of actinomycin $D$ on production of interferon and virus titres in measles-infectod chick fibroblast cultures.

H.Ep.2 cells infected with the 'Edmonston' strain of moasles virus were disrupted by three cycles of freezethawing. This fluid, which after contrifugation and membrane filtration contained $10^{3.7}$ plaque producing dosos $/ \mathrm{ml}$., was usod as inoculum for chick embryo fibroblast monolayers maintained at $37^{\circ}$ in modium 199 with 5 per cent foetal calf serum. After 8 days the whole cultures were disrupted as described and assayed for measles virus by plaque production in $H . E p .2$ cell monolayers and, after high-speed centrifugation $(120,000 \mathrm{~g})$, for interferon. The end-point of interferon titration was expressed as the reciprocal of the dilution causing 50 por cont inhibition of plaque formation by Sindbis virus in chick fibroblast monolayers.

Both yield of infectious virus and interferon production wore compared from normal cultures and from cultures of cells pretreated with actinomycin $D$ at a concontration of $0.01 \mu \mathrm{g} / \mathrm{cm}^{2}$ of monolayer $(0.1 \mu \mathrm{g} / \mathrm{ml}$.) for $4 \mathrm{~h}$.

Normal cultures yielded fewer than 10 infectious particles $/ \mathrm{ml}$. with an interferon titre of 12 while actinomycintreated cells yielded $10^{2.7}$ infectious particles with undetectablo interferon production. These results support the view that actinomycin allows increased virus yield by inhibiting interferon production. Thus monolayers of a cell typo normally showing a high degree of 'resistance' to measlos virus and to which this virus must normally be 'adapted' by repeated passage are rendered more suscept. ible by supprosision of interferon production.

Further oxperiments are now being carried out to characterize this interferon and examine production of measles interferon in other cell systems.

This work was supported by Commonwealth Serum Laboratories and University of Queensland research grant No. 243.

C. D. Anderson *

J. G. Atherton

Department of Microbiology, University of Quecnsland, Brisbane.

* Present address: Commonweaith Serum Laboratories, Parkville, Victoria, Australia.

I Reich, E., Shatkin, A. J., and Tatum, E. L., Biochim. Biophys. Acta, 53, $132(1961)$.

${ }^{2}$ Reich, E., Franklin, R. M., Shatkin, A. J., and Tatum, E. L., Proc. U.S. Nat. Acad. Sci., 48, 1238 (1962).

${ }^{3}$ Simon, E. H., Virology, 13, 105 (1961).

4 Kingsbury, D, W. Biochem. Biophys. Res. Commun., 9, 156 (1962).

${ }^{5}$ Barry, R. D., Ives, D. R., and Cruickshank, J. G., Nature, 194, 1139 (1962),

- Rotem, Z., Cox, R. A., and Isaacs, A., Nature, 197, 564 (1963).

7 Bukrinskaya, A. G., and Zhdanov, V. M., Nature, 200, 920 (1963).

${ }^{8}$ Gifford, G. E., and Heller, E., Nature, 200, 50 (1963).

- Heller, E., Virology, 21, 652 (1963).

${ }^{10}$ Friedman, R. M., Nature, 201, 848 (1964).

\section{Lipid in a Purified Preparation of Tomato Spotted Wilt Virus}

ELECTRON micrographs of tomato spotted wilt virus (TSWV), when stained by uranyl acetate or lead hydroxide, revealed the presence of an envelope surrounding an aggregate of several heavily staining spheroidal particles ${ }^{1}$. The envelopes stain only lightly with these reagents, suggesting that the envelopes contained lipid. Accordingly, a purified preparation of the virus was examined to test this hypothesis. By direct extraction with organic solvents the preparation was shown to contain about 20 per cent extractable lipid. Thin-layer chromatography of these extracts revealed a number of spots which gave a blue colour when treated with a molybdonum-based stain ${ }^{2}$. Although lipid has long been known to form part of some animal viruses there is no record of the presence of a lipid in a plant virus.

The virus was a sample of strain $E$ of TSWV. The virus was extracted from systemically infected leaves of Nicotiana glutinosa by homogenizing them in the buffer solution at $p \mathbf{H} 7$, removing non-viral material by alternate cycles of low- and high-speed centrifugation followed by two cycles of sucrose density-gradient centrifugation as described by Best and Palk ${ }^{1}$. The virus was identified in the light-scattering band of the density-gradient tubes by its infectivity and characteristic size and shape under the electron microscope ${ }^{1}$. After removing the sucrose and buffer salts the virus was freeze-dried and then stored over phosphorus pentoxide.

The dry virus was extracted for lipid by the microextraction method described by Thomas ${ }^{3}$, using the 